\title{
Tasman Epiphanies: The 'Participant History' of Alan Ward"
}

\section{PETER HEMPENSTALL \\ University of Canterbury}

The recent emphasis on transnationalism as a context for historical explanation, often ignoring the nation-state altogether, is a useful tool with which to examine the relation between New Zealand and its close neighbour Australia. It has encouraged the rebirth - or, as one historian has put it, the 're-membering' - of an old concept, Australasia. Donald Denoon argues that Australasia is 'a repressed memory' for our trans-Tasman cousins that had vague geographic limits but was nonetheless a political and cultural entity for a long time. It included Australia, the British part of New Guinea, New Zealand, Fiji and other British possessions attached to the region. Colonial lines drawn on maps created this region, and new lines drawn at Australian federation, in 1914 and again at independence for the Pacific colonies, reshaped the region, shrinking it radically until it disappeared from Australians' view. But Denoon insists that it still exists today, as an interactive region stretching from Dili to Dunedin, of which Australia is the centre of gravity. ${ }^{1}$

But from a New Zealand perspective, Australasia remains an unpersuasive geographical concept. The literal coverage suggested by the term couples hegemonic Australia with a large, diffuse and alien Asia, a spatial construct that is undermined by the present crisis in Timor Leste and Indonesia's coldness towards Australia because of her acceptance of West Papua refugees. Australasia does not satisfactorily encapsulate the antipodean identities of two migrant settler societies whose past, present and future are intimately tied together, and the islands of the south-west Pacific where small offshoots of these migrant societies exist. A better concept is that which James Belich says operated as an organic entity in the nineteenth century but with Australian federation died away - the Tasman world. ${ }^{2}$

In fact, it can be argued that the Tasman world never died and indeed has strengthened. ${ }^{3}$ New Zealand and Australia share a history that is rich

I am indebted to two anonymous reviewers for adding crucial information and references to this essay. 
and deep across a range of institutions, social structures and events. And that history accommodates communities, individuals and encounters on Melanesian and Polynesian island frontiers, as on the mainlands of each nation state.

One of the ways to re-tell such connected history is through the lives and influence of significant trans-Tasman individuals who operated easily within an expanded Tasman world. One such is the Kiwi and Pacific historian Alan Dudley Ward, who has lived on multiple mainland and island frontiers and has recently retired from involvement with the Waitangi Tribunal where he was a senior contract historian since the late 1980s. A study of his career at this moment of change, and of the influential body of writing he has created, provides a navigable pathway into understanding the self-consciousness of being Kiwi within the Tasman world and how the region might be connected together in the historical stories we tell about it.

Alan Ward is today Emeritus Professor of History at the University of Newcastle in Australia. He was born in 1935 into one of the pioneer Pakeha families inland from Gisborne. It was a family for whom the old term Poverty Bay was aptly named, for Alan's father, though trained in law, retreated from practice to become a small dairy farmer on a 40-acre section. This was Belich's 'tightening' New Zealand ${ }^{4}$ of the 1930s, with a social atmosphere of moral evangelism, narrow conformity and apparent racial harmonization. Maori, in rhetoric and symbol, if not in social relations, were incorporated as a re-invented, European-descended, or Aryan, race of honorary, slightly darker, whites. Alan grew up in a stern environment, in which probity and a steely morality were the highest values. Like other settler children, he mixed easily with Maori at school and he knew Maori stockmen and shearers from his maternal uncles' farms; one of his aunts married a local Maori. In Gisborne itself, a Maori gentry class passed muster in polite society - the Carroll and Pere families among them - but an informal segregation commonly operated in public places against rural Maori visiting the town.

Alan was bookish and enjoyed educational success at a succession of local schools, which he left at the end of 1952 for Victoria University College (VUC). Ward arrived in Wellington the model working-class Tory - from a family of battlers who believed strongly in private enterprise, voted National, yet looked to the state to fill the gaps in education, health and welfare that always lay in front of them. By the time he left university in 1956 for Auckland Teachers' College, however, he was an active Labour supporter. He recognized that he and other family members had been kept alive during successive medical emergencies by the health services of the welfare state, and he felt a great release of energies from the higher education which 
had reached into rural communities, for Maori and Pakeha alike, under the Labour administration of Michael Joseph Savage and his successors. Suspicious of banks, as well as absentee landlords (one of whom drew rent from his parents' limited income), and wary of the unions, Ward is prepared today to see himself then as 'socialist': committed to the state's servicing of the wider New Zealand community while contemptuous of those who 'bludged' off the state's resources. ${ }^{5}$

VUC was good to Ward. Though English was his first love and he wanted to be a school-teacher, he fell under the spell of Freddie Wood the historian - an Australian - and the stern Popperian Peter Munz. ${ }^{6}$ Ward discovered that history was a great adventure in ideas, which, courtesy of Munz, was infused with the riches of western European civilization and, through Wood, was rounded out with the skills of fine writing, debating historical interpretations and immersion in the documents. Ward was won for history, though not yet for Pacific history. That came through J.W. Davidson, who had been at VUC years earlier, where he was taught by J.C. Beaglehole. Beaglehole helped to erode in Davidson any empire sentiment or Anglo-centric views. Davidson embarked on an anti-colonial trajectory that was consonant with his later work as a constitutional advisor for new states in the Pacific. But he cut his teeth as a 'participant historian' on a Masters thesis for Beaglehole, examining the Scandinavian settlements in New Zealand, where he was able to walk over the farms they cut out of the rugged scrub and talk to survivors of the original migrants. ${ }^{7}$ From there, Davidson carried his anti-colonial tendencies to Cambridge where he studied the Pacific from the centre of empire. After a war spent writing naval handbooks on the Pacific and studying African politics, Davidson was recruited - courtesy of another influential New Zealander, Raymond Firth - for the world's first Chair in Pacific History at the fledgling Australian National University (ANU) in Canberra. ${ }^{8}$

At ANU, Davidson continued his role as promoter and practitioner of participant history. He championed the notion that experience of life was part of the historian's stock in trade. Davidson handpicked his students and he wanted them to 'get into the field' and to write on topics congruent with their background and experience. ${ }^{9}$ Through fieldwork, he believed, the historian became a participant in history. At another level, Davidson's notion of participant history meant that historians could participate in contemporary Pacific Island affairs and contribute to the outcomes they would later write about. In Davidson's case, this involved the formal role of constitutional adviser to a succession of Island territories in the process of decolonization, beginning with Western Samoa in 1959 and ending with Papua New Guinea at the time of his death in $1973 .{ }^{10}$ 
Of all Davidson's students, Alan Ward comes particularly close to this public service ideal. ${ }^{11}$ Ward's route into participant history also took a local and anti-colonial direction. The Maori people had not figured in the classical history training and story-telling he had experienced. But his country roots made Ward want to study Maori settlement in the Gisborne region, known from his childhood and through the folklore connected in every Kiwi's education with the exploits of the east coast guerrilla leader, Te Kooti, and the founding of the Ringatu church. Encouraged from home, where his knarled and undemonstrative father nevertheless showed he was proud of his son's university accomplishments, Ward studied during 1957-1958 for a Masters degree in history. Assisted by the Maori Affairs Department, he fell into one of those projects of public history which the New Zealand state has developed into an art form. ${ }^{12}$ It was a study of the East Coast Maori Trust, a statutory trust created in 1902 to rescue Poverty Bay and East Coast lands from indebtedness to mortgagees and forced sales - a fate that commonly overtook Maori land after the 1860s, once customary tenure had been replaced by negotiable titles. It was a singular if infrequent success story: an institution and community that were able to retain land in Maori ownership in the face of nineteenth-century losses caused by state settlement policies, and to plan development with and through the local Maori communities. ${ }^{13}$

His thesis introduced Alan to the intricacies of land court records, the sweep and drudgery of parliamentary papers, and explanations by Maori themselves about their past. He began to apprehend where Maori stood, or did not stand, within the rural economy of New Zealand and he gained a respect for their aspirations, which he dimly realized had been undermined for 100 years by the power of the settler state. This insight connected with Ward's visceral concern about land, growing out of his rural childhood, and gave him the two themes that became the sustaining threads of his professional activity and writing.

None of this is a tale of heroic enlightenment or sudden conversion to a missionary career on behalf of dispossessed indigenous people. Ward was an angry young man and by his own admission did not behave well at university. He was something of a 'pompous prick', excessively earnest, a touch puritanical. Ward was highly sensitive to class, regarding with distaste the tweedy, donnish atmosphere of the university. 'My history was a series of falling outs', he admits. Ward went teaching, spent a year training for the Anglican priesthood in 1959, then discovered Rome. But these too were 'falling outs' rather than falling in. He was intellectually drawn to Roman Catholicism through the works of Newman and Ronald Knox, but 'intellectual pride' drove him out again when he discovered that his notion of 
prayer did not seem to work in the material world. Ward remained then, and for the rest of life, a 'Christian humanist', his heroes then as now Erasmus and the Elizabethan Reformation bishops of England. He retained a vague inkling that the world holds some numinous dimension beyond the material; Maori have been important to him in strengthening that.

A short stint in what was then the Department of External Affairs during 1961 intensified his anger. After working on a brief that entailed studying the profile and policies of the South African Prime Minister Verwoerd, he was corrected by his section head for recommending that New Zealand should support the Afro-Asian nations in censuring apartheid at a forthcoming Commonwealth conference. Keith Holyoake, Prime Minister and Foreign Minister, in the event supported the Afro-Asian position rather than that of Harold Macmillan and the Australian Robert Menzies, who were trying to appease Verwoerd and keep South Africa in the Commonwealth. But Ward felt that the Department was prone to take expedient rather than principled positions and found it hard to live on such compromises. He walked out after ten months and got a job on the wharves. Impetuosity and anger - some of it inherited from his father - kept driving him to sudden switches of direction. After missing out on scholarships that would have taken him to the UK on the usual route for Kiwis and Australians wanting to go on to higher postgraduate studies, Ward made for the ANU in 1962, with a PhD topic about Anglican missionaries in the Solomon Islands. But his Christian enthusiasms leached all the way out in Canberra. He met his future wife there (an Australian working for the public service), but this failed to settle him. His restlessness drove them back to Auckland. They started a family and Alan taught at Mount Roskill Grammar School, fiddling with historical research along the way.

It was in Auckland that he finally found a topic to sustain his interest, one that had been fermenting since his earliest days on the east coast. He called it 'Towards one New Zealand', and its inspiration came from the Hunn Report of 1961 which revealed the hitherto assimilationist agenda that underlay New Zealand's national policy towards Maori. ${ }^{14}$ It made Ward aware of the dilemmas facing policy planners as New Zealand coped with the pressures from urban migration of rural Maori, but importantly, it threw up the central question, how had these policy decisions been made? That started Ward on an examination of the nineteenth-century connection between the land and the law, which he grasped was the prism through which much of New Zealand history (and its difference from that of Australia) was refracted. Significantly, the person who saved him at this point was J.W. Davidson, who took him back at the ANU in 1965 to start afresh on a PhD and whose supervision was crucial to bringing Ward's project and historical thought to 
fruition. The link between Pacific history, New Zealand and Maori issues, and Australian institutions was thus engraved on Alan Ward, and a small step taken towards a restored Tasman world emphasis.

The PhD thesis of 1967 became the book A Show of Justice. Racial 'Amalgamation' in Nineteenth Century New Zealand. ${ }^{15}$ Described as ' $[\mathrm{t}] \mathrm{he}$ outstanding work of general history on nineteenth-century indigenous/ colonial history ... a work of nuance and learning, ${ }^{16}$ this has been an extraordinarily influential book in New Zealand, in showing how the organic relationship forged between Maori and European authority in the nineteenth century was progressively undermined and subverted by the settler state's unwillingness to 'amalgamate' with Maori as equal partners, and through a constant reframing of statute law to relieve Maori systematically of their lands. ${ }^{17}$ It was done by court-sanctioned, overt and covert individualization of land titles, which struck at the heart of Maori communal forms of property holding. At the same time, Maori were denied the capital that was flowing to Pakeha from London banks, unable to develop their lands and so achieve a balanced economic relationship with the parent state. Maori were increasingly marginalized, on just such a coast and in the valleys where Alan Ward grew up. What increased the wound, already inflamed to the point of eruption as Ward was writing, was the smug belief of the Pakeha population that New Zealand race relations were vastly superior to those in Australia or indeed in any of the other immigrant nations around the world. ${ }^{18}$

A Show of Justice was not a one-dimensional polemic against racist, colonial rapacity - though Ward was at this time impressed by Fanon's devastating critique of white racism. ${ }^{19}$ In a series of measured judgements, he demonstrated how the system was still of benefit to Maori: it limited open settler violence, allowed multi-racial schools and sanctioned interracial marriage; it let Maori into unions; and it also provided some rural proximity in work and leisure that had the appearance of community-based bi-racialism. Maori retained some land, and worked it with some success - as in the case of the Maori land trust on his own east coast, which wound up in the 1950s and returned control of the land to incorporations of its Maori owners. Most Maori sought advancement with and through the mainstream institutions, not through separatism, and at least the New Zealand amalgamation polices were better than the 'protection' on reserves that Australian Aborigines were forced to endure. The book was a benchmark in New Zealand, though it started also to have an influence among Australian historians once Ward began inserting Maori history into Australian history teaching. ${ }^{20}$

Ward's appointment to teach history at La Trobe University in Melbourne in the late 1960s was the springboard. Melbourne was a world away from his New Zealand experience. La Trobe itself, as one of the new generation 
universities that sprang from federal government expansion of tertiary education, was more open, flexible and cross-disciplinary than anything Ward had experienced at VUC, and less stuffy. Inside and outside the university, Vietnam war protest was raging and tense debates took place over Soviet intervention in central Europe. Alan entered into all this with zest, though he did not take to Melbourne and faintly disapproved of the way Australians flaunted their privileged lifestyles but lived in ignorance of the dark side of their history of relations with the Aboriginal people. He sought refuge in his growing family life. Characteristically, he regarded family as 'the fundamental value which redeems the viciousness of life'. ${ }^{21}$ Ward contended with that 'viciousness' by joining the Australian Labor Party to help address the class struggle that he saw going on all about him. He shared what he thought was probably the general Kiwi feeling at the time: that the New Zealand system of state education and health care was superior to Australia's. Ward believed individual Kiwis might make a difference in educating Aussies to that difference.

Serendipity - that deus ex machina much beloved of biographers - suddenly intervened to extend the reach of his Tasman world. In 1971, Ward was catapulted onto Australia's rapidly aging colonial frontier in Papua New Guinea. He was invited to teach at the even newer university in Port Moresby to allow Ken Inglis, the Professor of History, some relief in Canberra while he wrote a book. Though Ward had no particular pioneer ambitions, he joined a band of expatriates (some of them exiles) who were seeking to make a difference. ${ }^{22}$ Ward was thrust into the creative ferment at the young university, where history courses suited to an emerging nationalism were being crafted. The infrastructure of government was still being built, and local élites were being trained, belatedly, to take over the transactions of a centralized state where no tradition existed, even of regional government in indigenous hands. A wholly new national community was being imagined from the ground up, while the Australian colonists fretted about the problem of re-imagining Papua New Guinea as nation rather than as 'backyard'; a backyard best avoided and kept at arm's length. ${ }^{23}$

In this complex society of Anglo-Australians and colonial exiles wracked by its own fears and ambiguities, ${ }^{24}$ Ward discovered to his surprise that Maori-Pakeha relations had lessons to teach when inserted into the frontier where law met the issue of land. The elderly and respected missionary Percy Chatterton ${ }^{25}$ heard about Ward's expertise in the history of land matters in New Zealand. He recommended Alan to the newly emerging Pangu Pati led by Michael Somare, to advise their members in the House of Assembly on a series of land bills being introduced by the Australian administration. Accelerating decolonization was creating anxiety among Papua New Guinea 
élites as the culturally conservative Australian administration retreated and opened a range of choices to the new leaders. Old certainties, like the communal holding and transfer of land rights by tradition-sanctioned processes, seemed to be unravelling. Ward read the bills. He says the experience was reminiscent of the revelation he had about the real situation for Maori in the 1860s. Australia was setting out to introduce a system where individualization of titles and their transfer into hands outside the local landholding group would be all too easy to accomplish. The plan amounted to an 'agrarian revolution' akin to that which had stripped Maori of their land. Ward's learned mistrust of the colonizing state led him to see a conspiracy, led by C.E. Barnes, Australia's Minister for External Territories, with powerful planting interests and overseas investors waiting on the sidelines. He dashed off a paper, helped Chatterton make 70 cyclostyled copies, delivered them to members of the House and retired to his teaching. The next he heard, the bills had been pulled from the House because of criticism by 'a New Zealand expert'. ${ }^{26}$

Ward was both elated and mortified. He had failed to recognize the sensitivities of colonial politics and thought his 'briefing paper' would remain just that: an instrument to arm the new Papua New Guinea élite with a critical standpoint from which to judge the bills. Among Australian colonial administrators, he had suddenly instead acquired a reputation as a troublemaker. Ward admits he must have seemed the archetype of the outside Pacific consultant in those years, bearded and jandaled, arrogant with the power delivered to one of his comparative youth. He was snubbed by Australian officials, though it did not affect his standing at the university or among Papua New Guineans. Ward regarded the local Motuan élite around Port Moresby as a people like the Maori - Austronesian speaking, hierarchical, with an honourable and hospitable code of behaviour. Being non-Australian also gave him an advantage with the locals, and he was invited back to Papua New Guinea in 1972 as consultant to the Commission of Enquiry into Land Matters set up under pressure from the Pangu Pati.

This period drove home to Ward the conviction that new states need not abandon underlying customary forms of landholding. Papua New Guinea should be free to develop a variety of property-holding models that protected the small-holding villagers (for whom the subsistence economy was still the only real form of social security) while providing security of tenure for cash cropping. But he learned, too, the lesson of potential corruption by the development process, as small expatriate planters had their plantations compulsorily purchased by the new indigenous government, while big interests were able to do deals to retain their holdings and expand. These experiences stripped Ward of any remaining romanticism about indigenous 
leaders: powerful Big Men and politicians could just as easily monopolize land and divert resources into their own hands. Colonialism was not the all-consuming, western bogeyman that critics made it out to be; custom could also be broken open from the inside. ${ }^{27}$

He learned this lesson again to his professional cost in the new state of Vanuatu, previously the New Hebrides, during 1981-1982. He took an appointment as Director of Rural Lands for the government of Walter Lini's Vanuaaku Party, impelled partly by J.W. Davidson's 'participant' philosophy to make connection with local problems in an executive capacity, partly by a residual suspicion of windy academicians deconstructing the world from the safety of their studies. His responsibility in Vanuatu was to supervise and regularize the transfer of old freehold titles, which settlers and companies had held under the joint administration by France and Britain, to the limited leaseholds permitted under the new constitution. Ward discovered that the government also expected him to carry out the stripping of custom land, without compensation, from those who had taken part in the pre-independence coups of 1980 . He refused. Ward was temperamentally disposed in favour of the battlers, even those naively involved in rebellion. They might face expropriation for their sins but should not do so without compensation for the state's actions. Ward was caught up in a deteriorating situation, as he also opposed the restrictive form of citizenship under the constitution, which discriminated against mixed race people in Vanuatu. He faced the threat of peremptory deportation for failing to do the government's dirty work - the fate of other dissident expatriates. Hearing rumours in 1982 that he was on the list for a notorious 'green letter', Ward jumped first and resigned, 15 months into his appointment.

Thus Ward added to his armoury another lesson: beware the regulatory state where efficient filters against corruption have not been put in place. As far as Ward was concerned, the naked imperialism of the French on the eve of Vanuatu's independence was succeeded by a black counter-racism on the part of the independent ni-Vanuatu. It made him cynical about unconditional support for the ethnic state, and more determined to find and express in his writings an irreducible set of principles for living in the pluri-ethnic communities that make up the Tasman world's sphere of influence. ${ }^{28}$

New Caledonia rammed that message home more sharply when friends and associates among the Kanak political movement, including Jean Marie Tjibaou, were assassinated in the political troubles of the 1980s. Ward's experience in New Zealand, Australia and Papua New Guinea was giving him an unusually broad sense of the problems thrown up by the confrontation between indigenous land use, settler law and the imperatives of western colonial rule. He was also developing a sense of mission that 
grew naturally out of his austere background and ingrained values. He went to New Caledonia in 1979 to study the problems of a settler society like New Zealand, with two contending racial communities and growing conflict over historical land injustices; he also wanted to educate Australians out of their smugness about settler history and their misconceptions about the forces of civil strife building off their Pacific coast. ${ }^{29}$ Working in an atmosphere of hostility emanating from his French minders, Ward argued that the spoliation of Kanak lands was comparable to that suffered by the Australian Aborigines, and that the degradation of many Melanesians in New Caledonia had its closest Pacific parallel, again, in Aboriginal Australia.

Ward predicted the vicious conflict that ensued in New Caledonia in the 1980s, and he enunciated the first of his principles for living together in stable Pacific states: the solution to local compromises in situations of fluctuating power between settler and indigenous communities lay with the local communities, not with the colonizing power directing proceedings. France should progressively withdraw in favour of an independent New Caledonia that recognized Melanesian primacy but made liberal terms for non-Melanesians whose home New Caledonia had also become. The local state would then be forced to work out a collaboration on the ground among both indigenous and settler groups. 'Only with responsibility will come real wisdom', was Ward's optimistic, indeed, given what later occurred in New Caledonia, over-optimistic conclusion. ${ }^{30}$ It was also an unintended irony considering Ward's own later experience in Vanuatu.

Obliging the locals to come to terms with one another became a core principle of Ward's recipe for stable post-colonial communities. New Zealand's record in achieving this remained Ward's inspiration, and through the 1980s he was drawn into the new political dynamics of the Waitangi Tribunal, set up by the Labour government in 1975. A Show of Justice had identified the issues for Maori that had contributed to the establishment of the Tribunal: redress for the colonial theft of resources, resentment of Pakeha paternalism, the intense desire to retain a distinct Maori identity and a search for a measure of self-determination within a modern nationstate with a Pakeha majority. ${ }^{31}$ Ward was brought in as an historian for the Tribunal itself, his task to pick apart the contending historical stories about alleged breaches of Treaty principles told by Maori claimants on the one hand, and the Crown in defence of its prerogatives and past record on the other, and to provide a balanced appraisal for the Tribunal to use in its determinations. This was the particular brief of his national overview report, which was also intended to facilitate district-based research for the claims process more quickly. ${ }^{32}$ His work, which stretches over 18 years to his recent retirement with the presentation of the Tribunal's report on the 
Hauraki claims, has led to a closer and more pensive reflection about the place of the Waitangi Tribunal in New Zealand's national life, together with its lessons for the wider Tasman world. It has also prodded his thinking about the nature of history itself, its possibilities and limitations.

Ward's first consolidated statements of his view on the Tribunal process made his allegiances clear. ${ }^{33}$ Maori grievances were of long historical standing and they carried substantial weight. The chiefs in 1840 had ceded the government (kawanatanga) of the land but not their lands nor their rangatiratanga, the rights and responsibilities of chiefs, tribes and individuals towards their property and towards each other. Yet in the confiscations during the land wars of the 1860s, and through the Land Acts administered by the courts, both lands and tribal authority were lost. Maori had never accepted this situation. Their resentment had taken a century and more to reach a boiling point that led to the land occupations of the 1970s and the threatened violence of the 1980s, as Maori raised a defence of their treaty. A deeply polarized New Zealand nonetheless began a comprehensive re-examination of its history, with serious regard to Maori perspectives - and Ward would submit this as an example which Australia, or at least its government leaders, characteristically ignored because it came from across the Tasman - that put the Treaty at the centre of the national story. ${ }^{34}$ Setting up the Tribunal to make recommendations to government on breaches of Treaty principles in the present day was one thing, but to extend its jurisdiction retrospectively to cover breaches since 1840, as the Labour government did in 1985, was, as Ward put it, 'something of an epistemological revolution', ${ }^{35}$ a revolution the government of the day did not realize would open the whole of New Zealand's colonial history to scrutiny.

Tribunal proceedings have been increasingly dogged by controversy since those days, as the claims steadily mount, the settlements take years to emerge and the balance of political influence shifts in the community. A variety of interest groups criticizes the 'gravy train' for lawyers and bureaucrats, while many Pakeha resent the 'special privileges' they see Maori as getting; even historians worry about the politicized nature of the historical accounts that the process encourages.$^{36}$ Ward has retained a steadfast attitude to the justice of the process. In 1986, Justice Eddie Durie said of the Treaty that it could be read as the 'heads of agreement for a bicultural development in partnership'. ${ }^{37}$ This encapsulates too the view of Alan Ward. He is on record as saying that the Treaty is only one strand of a complex, evolving relationship between Maori and Pakeha, a 'subtle instrument of enormous worth', part of an enlarging vision for the future. ${ }^{38}$

The Treaty and its historical imprint through the Tribunal represent everything Ward has learnt and carries to the Tasman world about bringing 
disparate indigenes and immigrants together: the need to contract together to the enterprise of nation-building, based on the critical relationship between law and the land. Australian Papua New Guinea, French New Caledonia, independent Vanuatu, the east coast of New Zealand and Poverty Bay - these are the theatres in which Ward accumulated and crafted together a difficult realization of this principle.

Paradoxically, Ward is not optimistic that an Australian treaty with the Aboriginal people would achieve the same ends. The power of such a step by the Australian body politic would lie mainly in its symbolism for élites on both sides of the racial divide, rather than necessarily bringing in its train fundamental policy changes that would redefine the state's relationship with Aboriginals. ${ }^{39}$ Ward reminds Australians that the Treaty of Waitangi lay dormant among European New Zealanders for nearly 150 years until it was formally reinvoked in domestic law in 1975 - the political struggle to make it a live document was the key. ${ }^{40}$ In the meantime, Ward points to currents moving below the surface in Australia's relations with Aboriginal groups. The land rights and/or compensation recognized by the historic Mabo and Wik claims of the 1990s have been eroded by counter-legislation under a succession of conservative federal governments since 1996. But New South Wales Aboriginals, using monies accumulated in the Land Fund set up under the NSW Aboriginal Land Rights Act of 1983, have acquired urban and coastal properties with a high rate of return, as well as repurchasing crucial, symbolic properties in their home countries.

It is in such regional initiatives that Ward believes Australia may outstrip New Zealand in the future, where a dwelling on past grievances and the factionalism among some rural iwi delay the pragmatic deals that could be closed with the state. Ward, looking from across the Tasman, reminds Australia that there is as much money in the NSW Aboriginal Land Fund that grew out of the 1983 Act, as has been paid out in the whole of New Zealand with its more prominent national process for settlements. State and/or regional agreements are happening underneath the constraints in the Native Title process imposed by the federal government. Justice Eddie Durie brought back from the Northern Territory the idea of the claims casebook which is widely used in Waitangi Tribunal procedures today; joint ventures with local Aborigines in mining, tourism and pastoralism multiply across the states. And in both Australia and New Zealand, new efforts are being made to develop forms of land tenure to enable indigenous groups to manage fruitfully land which has been returned to them. 
The New Zealand settler experience and that of Australia are the two major components of the Tasman world, each containing a variety of subcultures, each with its own fraught relations with the people of the land. This world consists of a field of communities that takes in the south-west Pacific Islands that lie to the north and east of Australia and New Zealand. Alan Ward speaks to us out of that world, from a point somewhere between New Zealand and Australia, a point metaphorically in the Tasman Sea but encompassing a conception of the region broader than the boundaries of the two settler nation-states. That field has been historically shaped through the dialectical exchange of values and ideas and the influence upon policymakers of influential individuals. Alan Ward is one such. He apprehends a truth at the core of these communities: land is the key focus of the values and aspirations of their peoples, and the prism through which is refracted the relationship between tradition and modernity as the settler societies grow. ${ }^{41}$ Western property rights are a recent insertion into the region, and Ward's life and work are a testament to the struggle to bring the concept of land as an economic commodity into line with broader Pacific views of land as living space that provides identity. The historian Klaus Neumann remarks that Pacific peoples (he was speaking about the Tolai in Papua New Guinea) live in 'close-ups' in relation to land, with every position, place and feature of land named, identified and known. ${ }^{42}$ Ward is in fundamental agreement, and this view of the 'local' has informed all his work in Papua New Guinea, Vanuatu, New Caledonia, Australia and New Zealand. It has led him to advocating, openly and behind the closed doors of policy-makers on both sides of the Tasman, that the state should make available a flexible range of property rights, land tenures and use-holds.

$\mathrm{He}$ has also become less and less romantic about the way the Tasman world turns. His traditions are firm; his limits set. Sometimes his address to the world has a touch of the unbending prophet: 'secular sermons', one commentator has called them. ${ }^{43}$ The most delicate task in this region of recent immigrant nations among first peoples, as Ward now sees it, is to create 'viable communities out of ethnic mixes' ${ }^{44} \mathrm{He}$ is fond of quoting the Mexican novelist Octavio Paz, who writes that community exists only when humans of diverse kinds 'recognise themselves in each other'. ${ }^{45}$ Ward sees the rise of ethno-nationalisms - whether in New Zealand, New Caledonia, Fiji, the Solomons or Australia - as 'the crisis of our times' ${ }^{46}$ His life and work have revealed to him the historical entanglement of a host of differing societies within the region as a good if difficult thing: he would not be out of sympathy with the development of a creolized Tasman world - a gift of his life among Maori. His project has been about broadening the politics of identity beyond a scrutiny of the New Zealand navel, making old exclusions 
into new inclusions, and reclaiming a set of shared histories, though he remains unsentimental and unblinkered about the contest for power.

1 D. Denoon, 'Re-membering Australasia: A Repressed Memory', Australian Historical Studies, 34, 122 (October 2003), pp.290-304.

2 James Belich, Paradise Reforged. A History of New Zealanders from the 1880s to the Year 2000, Auckland, 2001, pp.46-47.

3 The author is part of a research project examining the interactive history of New Zealand and Australia during the twentieth century, whose results will be published in the book Remaking the Tasman World, Canterbury University Press, in preparation.

4 Belich, Paradise Reforged, pp.121-5.

5 Many of the details of Ward's life, and the quotations by him, are taken from recorded interviews in the possession of the author, 17 and 18 August 2002, Christchurch. I am grateful to Alan for giving more precise expression to some of my ideas in feedback on this essay, but he has not interfered with the judgements, which remain my responsibility. For a published interview with Ward, see Lloyd Ashton, 'A Sense of Anger', Mana, 28 (June-July 1999), pp.35-38.

6 On Munz, see Alan Ward, 'Historical Method and Waitangi Tribunal Claims', in Miles Fairburn and W.H. Oliver, eds, The Certainty of Doubt. Tributes to Peter Munz, Wellington, 1996.

7 J.W. Davidson, 'Understanding Pacific History: The Participant as Historian', in Peter Munz, ed., The Feel of Truth, Wellington, 1969, pp.11-24.

8 Doug Munro, 'J.W. Davidson - The Making of a Participant Historian', in Brij Lal and Peter Hempenstall, eds, Pacific Lives, Pacific Places: Bursting the Boundaries in Pacific History, Canberra, 2001, pp.101-2. See also Doug Munro, 'Becoming an Expatriate: J.W. Davidson and the Brain Drain', Journal of New Zealand Studies, 2-3 (October 2003-4), pp.19-43.

9 See Niel Gunson, 'The Study of Pacific History', in Brij V. Lal, ed., Pacific Islands History: Journeys and Transformations, Canberra, 1992, pp.4-6.

10 J.W. Davidson, Samoa mo Samoa: The Emergence of the Independent State of Western Samoa, Melbourne, 1967; C.C. Aikman, J.W. Davidson and J.B. Wright, 'Report to the Members of the Legislative Council of the Cook Islands on Constitutional Development', Victoria University of Wellington Law Review, 30, 2 (1999), pp.519-61.

11 The other is Brij V. Lal, who was a member Fiji's Constitution Review Commission in the late 1990s. See Brij V. Lal, 'While the Gun is Still Smoking: Witnessing Participant History', in Lal and Hempenstall, Pacific Lives, Pacific Places, pp.70-87; Doug Munro, 'Interview with Brij V Lal - Historian of Indenture and of Contemporary Fiji', Itinerario: European Journal of Overseas Expansion, 21, 1 (1997), pp.16-27.

12 See Bronwyn Dalley and Jock Phillips, eds, Going Public. The Changing Face of New Zealand History, Auckland, 2001.

13 A.D. Ward, 'The History of the East Coast Maori Trust', MA, Victoria University of Wellington, 1958. The Waitangi Tribunal's 2004 report, Turanga Tangata Turanga Whenua: The Report on the Turanganui a Kiwa Claims found the Crown had breached the Treaty in many respects in its dealings in the district. I am indebted to an anonymous reviewer for this information.

14 See Graeme Dunstall, 'The Social Pattern', in W.H. Oliver and B. Williams, eds, The Oxford History of New Zealand, Oxford, 1981, pp.425-6.

15 Canberra, 1974.

16 Damon Salesa, 'Korero: A Reflection on the Work of Judith Binney', The New Zealand Journal of History, 38, 2 (October 2004), p.281. 


\section{Tasman Epiphanies: The 'Participant History' of Alan Ward}

17 Vincent O’Malley, 'Unsettling New Zealand History: The Revisionism of Sinclair and Ward', in Doug Munro and Brij V. Lal, eds, Texts and Contexts: Reflections in Pacific Islands Historiography, Honolulu, 2006, pp.154-65.

18 Compare Keith Sinclair, 'Why are Race Relations in New Zealand Better than in South Africa, South Australia or South Dakota?', The New Zealand Journal of History, 5, 2 (October 1971), pp.121-7.

19 Alan Ward, 'Law and Law Enforcement on the New Zealand Frontier 1840-43', The New Zealand Journal of History, 5, 2 (October 1971), p.147.

20 That was the author's experience also when Ward became Professor at the University of Newcastle, New South Wales, in the 1980s and began to incorporate New Zealand and Maori history into the Pacific history curriculum. It was a revelation to students brought up to think tales of Aboriginal-settler conflict were unique and incomparable.

21 Interview 17 and 18 August 2002.

22 Among them were Hank Nelson, Jim Griffin, Bill Gammage and Ulli Beier, the Swiss-born 'cultural fixer' who had come from West Africa determined to give Papua New Guineans a literary voice in their own land. See Ulli Beier, Decolonising the Mind: The Impact of the University on Culture and Identity in Papua New Guinea 1971-74, Canberra, 2005; also Donald Denoon's essay, 'How Not to Write Biography', in Conversations. Occasional Writing from the Research School of Pacific and Asian Studies, Australian National University, 2, 2 (December 2001), pp.45-66. Poignantly, Ward was also in PNG at the time when Jim Davidson died of a heart attack while driving. Their relationship was as strong as ever.

23 Hank Nelson gives a good account of these anxieties in 'Observing the Present: Writing the Past', in Lal and Hempenstall, Pacific Lives, Pacific Places.

24 This crisis of the colonizer is well analysed in Nicholas Thomas, Colonialism's Culture, Melbourne, 1994. And of course George Orwell's Burmese Days, London, 1949, is the classic literary representation.

25 Percy Chatterton, Days That I Have Loved: Percy Chatterton's Papua, Sydney, 1974.

26 For a revised version of the paper Ward wrote for the members of PNG House of Assembly, see his 'The Future II: "Agrarian Revolution. Handle with Care", New Guinea and Australia, the Pacific \& SE Asia Quarterly, 6 (January 1972), pp.25-34. Not all his colleagues agreed: see Ron Crocombe's letter in 7, 2 (June-July 1973), p.63.

27 See Alan Ward's 'Papua New Guinea's Land Question', Meanjin, 34, 3 (1975), pp.358-64; also his 'Land and Law in the Making of National Community', in William Renwick, ed., Sovereignty and Indigenous Rights. The Treaty of Waitangi in International Contexts, Wellington, 1991, pp.115-29.

28 Interview, 17 and 18 August 2002.

29 Ibid. See also the Preface in Ward's Land and Politics in New Caledonia, Canberra, 1982.

30 Ward, Land and Politics in New Caledonia, p. 73; see also pp.77-78. Also Ward's 'The Independence Movement and the Plan Dijoud in New Caledonia', Journal of Pacific History, 15, 3 (July 1980), pp.193-9; and Michael Spencer, Alan Ward, John Connell, eds, New Caledonia, Essays in Nationalism and Dependency, St Lucia, 1988, p.19.

31 A Show of Justice, p.vii.

32 Rangahau Whanui, National Overview Report (Alan Ward), 1997. I am once again indebted to the anonymous reviewer for this added point.

33 Alan Ward, 'The Treaty and the Purchase of Maori Land', New Zealand Journal of History, 22, 2 (1988), pp.169-74; 'History and Historians Before the Waitangi Tribunal: Some Reflections on the Ngai Tahu Claim', New Zealand Journal of History, 24, 2 (1990), pp.150-67; 'Interpreting the Treaty of Waitangi: The Maori Resurgence', The Contemporary Pacific, 3, 1 (Spring 1991), pp.85-114. 


\section{Journal of New Zealand Studies}

34 Compare Claudia Orange, The Treaty of Waitangi, Wellington, 1987.

35 Ward, 'Interpreting the Treaty of Waitangi', p.100.

36 For instance: Giselle Byrnes, 'Jackals of the Crown? Historians and the Treaty Claims Process', The Public Historian, 20, 2 (Spring 1998), pp.9-23; Bronwyn Dalley and Jock Phillips, eds, Going Public. The Changing Face of New Zealand History, Auckland, 2001; Michael Bassett, 'Michael Bassett Talks to Virginia Larson', North and South, August 2002, pp.63-68; Giselle Byrnes, The Waitangi Tribunal and New Zealand History, South Melbourne, 2004.

37 Quoted in P.G. McHugh, 'Constitutional Theory and Maori Claims', in I.H. Kawharu, ed., Waitangi. Maori and Pakeha Perspectives of the Treaty of Waitangi, Auckland, 1994 (c. 1989), p.162.

38 Ward in Renwick, Sovereignty and Indigenous Rights, pp.124, 126-7. See also Alan Ward, An Unsettled History. Treaty Claims in New Zealand Today, Wellington, 1999. A condensed version is Ward's 1999 Stout Annual Lecture at Victoria University of Wellington, 24 May 1999: 'An Unsettled History', published in New Zealand Studies, 9, 2 (1999), pp.30-37. It makes the point that the Treaty of Waitangi was not drafted as a legal or constitutional document but to embody a political compact between Maori and the Crown to join under the Crown's aegis to build a functioning nation-state (to deal with new exigencies) where no functioning nation-state as yet existed.

39 Ward agrees with the Aboriginal magistrate Pat O'Shane on this point. See her 'A Treaty for Australians', in Renwick, Sovereignty and Indigenous Rights, pp.147-54.

40 Alan Ward, 'New Zealand Experience: The Treaty of Waitangi', in David Lemmings and Katherine Lindsay, eds, Treaties and Constitutions, Special Issue 5 of The Newcastle Law Journal, 2001.

41 Ward, Land and Politics, p.i.

42 Klaus Neumann, Not the Way it Really Was: Constructing the Tolai Past, Honolulu, 1992, p.77.

43 Mark Francis, 'Settler Historiography in New Zealand: Politics and Biography in the Early Colonial Period', Political Science, 52, 2 (December 2000), p.172.

44 Spencer, Ward, Connell, New Caledonia, p.1.

45 Ward in Renwick, Sovereignty and Indigenous Rights, p.115.

46 Alan Ward, 'The Crisis of Our Times: Ethnic Resurgence and the Liberal Idea', Journal of Pacific History, 27, 1 (June 1992), pp.83-95. 